\title{
PROPOSING WAQF PERCENTAGE MODEL (WPM) IN THE CONTEXT OF HIGHER EDUCATION
}

\author{
Anwar Allah Pitchaya, Mohamad Isa Abd Jalil ${ }^{\text {b* }}$, Megawati Soekarno ${ }^{c}$ \& Mohamed \\ Asmy Mohd Thas Thaker \\ ${ }^{a}$ School of Management, Universiti Sains Malaysia \\ ${ }^{b}$ Labuan Faculty of International Finance, Universiti Malaysia Sabah \\ ${ }^{c}$ Faculty of Psychology and Education, Universiti Malaysia Sabah \\ ${ }^{d}$ Kulliyah of Economic and Management Science, International Islamic University Malaysia
}

A PEER-REVIEWED ARTICLE

(RECEIVED - AUGUST 12, 2020; REVISED - SEPTEMBER 15, 2020; ACCEPTED - OCTOBER 1, 2020)

\begin{abstract}
One of the critical hurdles for universities in the next decade will be financial sustainability. Only those institutions that have stable economic structures and steady income flows will be able to accomplish their numerous undertakings and counter any current and upcoming challenges. This article is proposing the model of cash Waqf by income percentage within the higher education context. The proposed model was shown to an expert to develop a greater understanding of the Waqf Percentage Model (WPM) as well as appraise its applicability, suitability and prospects in the market. The discoveries from the interviews have supported the appropriateness of the Waqf Percentage Model in providing significant financial amenities. Consequently, the model is thought to be extremely beneficial in providing financial amenities by providing a substitute for conventional monetary establishments. The government should consider it carefully as this model could help them to reduce expenses on Waqf development. Finally, the Waqf Percentage Model can also be adopted by the Waqf institutions of other Muslim countries.
\end{abstract}

\begin{abstract}
ABSTRAK
Salah satu rintangan kritikal bagi universiti dalam dekad akan datang adalah kelestarian kewangan. Hanya institusi-institusi yang mempunyai struktur ekonomi yang stabil dan aliran pendapatan yang stabil yang dapat memenuhi banyak usaha mereka dan menghadapi segala cabaran semasa dan yang akan datang. Artikel ini mencadangkan model wakaf tunai mengikut peratusan pendapatan dalam konteks pendidikan tinggi. Model yang diusulkan ditunjukkan kepada seorang pakar untuk mengembangkan pemahaman yang lebih besar tentang Model Peratus Wakaf (WPM) serta menilai kesesuaian, kesesuaian dan prospeknya di pasar. Penemuan dari wawancara telah menyokong kesesuaian Model Peratus Wakaf dalam menyediakan kemudahan kewangan yang besar. Oleh itu, model ini dianggap sangat bermanfaat dalam menyediakan kemudahan kewangan dengan memberikan pengganti kepada institusi kewangan konvensional. Pemerintah harus mempertimbangkannya dengan teliti kerana model ini dapat menolong mereka untuk mengurangkan perbelanjaan pembangunan Wakaf. Akhirnya, Model Peratus Wakaf juga dapat diterima pakai oleh institusi Wakaf negara-negara Islam yang lain.
\end{abstract}

Keywords: Waqf, Higher education, Universities, Malaysia, Islam.

- Corresponding author: Mohamad Isa Abd Jalil, PhD, Labuan Faculty of International Finance, Universiti Malaysia Sabah Labuan International Campus, 87000 Federal Territory of Labuan, Malaysia. Email: isa@ums.edu.my 


\section{ANWAR ALLAH PITCHAY, MOHAMAD ISA ABD JALIL, MEGAWATI SOEKARNO \& MOHAMED ASMY MOHD THAS THAKER}

\section{Introduction}

Just like most Islamic countries, the practice of Waqf in Malaysia was adversely affected by colonial governance. Waqf is an Islamic voluntarily contribution which was recommended by Prophet Muhammad (peace be upon him - hereinafter PBUH) ${ }^{1}$ from the early age of Islam (Abas \& Raji, 2018). The word Waqf is an Arabic term which means "restraining", "prevention" and "stop". The Islamic decree acknowledges it as one of the altruistic acts that become a source of fund for economic and social development (Hassan, Hasan, \& Rashid, 2017). It can be illuminated as holding the money for the social purposes where it is performed to empower the poor to build a better society as well as promoting the philanthropic activity (Hasan, Hassan, \& Rashid, 2019; Ihsan \& Mohamed Ibrahim, 2011). Traceable to the $14^{\text {th }}$ century Malaccan Sultanate, Waqf practice in Malaysia commenced following the acceptance of Islam, where some of the Waqf properties, were primarily mosques and Islamic schools (Wu, 1975). Salleh \& Muhammad (2008) stated that the Waqf practice went through remarkable adjustment during the post-colonisation period regarding the functions of trustees. Further changes are the restructuring of Waqf properties in the country due to the absence of Waqf deeds which rendered some of the said properties as incapable of being considered as Waqf.

Waqf through higher education is a significant asset in the development of the Muslim community. Waqf in higher education will not only provide opportunities and facilities for the public to gain knowledge, but it is also an institution that offers an avenue for Muslims to do good deeds. In both Malaysian public and private universities, the generation of income through endowments have recently garnered attention as a sustainable financial tool. Being a non-profit organisation, public universities' endowment reflects the capacity to obtain revenues through grants and other avenues in demand. To accomplish the institutional mission, goals, or objectives as well as to achieve a surplus, they need to maintain productive processes projects at a steady or growing rate (Wan, 2017).

To fulfil the Education Ministry's determination to allocate greater access to higher education, Malaysia will be required to upgrade to a more top-quality tertiary education to almost double the students over the next decade. Seeing that financial sustainability will be one of the primary obstacles for academic institutions in the next decade, universities will be required to furnish themselves with the robust monetary support of unencumbered income flow to confront future challenges and achieve their numerous targets. As well as different starting points, every university today has its strengths, weaknesses, challenges and aspirations. The composition, function and operating model of the academic community have to be tailored to the university's explicit context based on its history, present condition, and its precedence. Consequently, to ensure that universities can adopt the elements that are best suited to their situation and pace, any execution needs to be designed in a modular manner.

Being a part of the Ninth Malaysian Plan, Cash Waqf is viewed as a major economic initiative in enriching the Muslim community in the country. Based on the Malaysian context, the sole trustee (Mutawalli) of Waqf in a state is its respective State Islamic Religious Council (MAIN). Hence, any public university needs to obtain the consent from MAIN to be a Waqf administrator (Nazir), a hurdle that must be settled by the administrators to implement Waqf in the university (Nor Suziana \& Noor Inayah 2017a; Nor Suziana \& Noor Inayah 2017b). Although the international Muslim community is exposed to the Waqf practice, trying to assess the depth of their knowledge of the said practice has been futile. In general, the awareness of the obligation of implementing Waqf practice among the Muslim community is vital, especially for the welfare of those in need (Latiff Azha, 2013). The development of the endowment has grown alongside the development of the country, which brought changes in Waqf activities that are more focused on cash Waqf (Ahmad, Abd Rahman, year).

However, the present model of cash Waqf is not capable of boosting the collection of cash Waqf consistently. Therefore, we aim to address the following research question:

\footnotetext{
${ }^{1}$ It is highly encouraged in Islam that, when any prophet's name is mentioned, we have to say "peace be upon him" after mentioning any of the prophets' name.
} 
1. What is the practice of Waqf in the context of public tertiary institutions in Malaysia?

2. What is the relevant model that could generate sustainable cash Waqf among the Malaysian public institutes of higher learning?

\section{Literature review}

Being a public Waqf, Waqf Share Scheme (WSS) is practised in several Islamic and Muslim minority countries such as the United Kingdom (UK), Indonesia, Kuwait, and most significantly in Malaysia. The objective of the scheme is to accumulate public funding and to disperse these funds for upgrading the societal wellbeing. Abdel Mohsin (2013) listed the modus operandi of the WSS is generally as follows: 1) any specified institutions appointed by the government may establish this scheme and become the trustee or Mutawalli. 2) Next, the named trustee will issue Waqf shares in different values and sell the shares to donors for a specific project. 3) The donors can then buy the shares according to their affordability. 4) In return, donors will receive cash Waqf certificate as the evidence for purchasing the Waqf share with a specific amount and project. 5) The trustee will manage this collection from the selling of Waqf shares in term of investing the funds. 6) Finally, the revenue generated from the investment will be used to finance the specified projects. Abdel Mohsin (2013) declares that despite the absence of any explicit details on how these countries invest the accumulated cash Waqf, this scheme has successfully benefited the beneficiaries in term of providing goods and services. Gadot (2006) said that in the 1990s, WSS gained popularity and had been widely accepted as a fund-raising scheme, which will later be invested (cited from Abdel Mohsin (2013). The investment revenue created has financed different types of projects such as constructing mosques and religious schools, building religious centre, providing physical amenities, financing medical services, maintaining the religious infrastructure, purchasing vehicles for Da'wah and especially, developing current Waqf lands for the Muslim community (SIRC Annual Report, 2009).

A public Waqf practised in Singapore, Bahrain, and South Africa is the Deposit Cash Waqf System (DCWS) (Ismail Abdel Mohsin, 2013). The modus operandi of DCWS begins where the donors donate directly to Waqf institution with cash deposits to a specific bank account. Secondly, the bank would invest the cash Waqf based on the agreement with the Waqf institution. Furthermore, lastly, the Waqf institution will obtain the generated revenue after investment which will be routed to the predetermined charities.

Abdel Mohsin (2013) stated that this scheme succeeded in providing various services and goods essential to societies. Beginning of the twentieth century in Singapore, under the Muslimin Trust Fund Association, which was founded on 31 August 1904, this scheme came into existence when Alsagoff and Co. along with other Muslim businesses and individuals contributed cash Waqf to be invested. Cizakca (2000) stated that the primary objectives of this investment were to finance the burials of underprivileged Muslims, gave aids to Muslim orphans as well as to the Alsagoff School besides other funding charitable projects.

Compulsory Cash Waqf Scheme (CCWS) is a public Waqf which has been practised solely in Singapore. Abdel Mohsin (2013) demonstrates the modus operandi of CCWS as follows:

1. Firstly, the Muslim employee's salary is deducted through the Central Provident Fund (CPF) Board, i.e. Singapore's national social security organisation;

2. Secondly, monthly contributions of between US\$1 and US\$7 are made by Muslim employees; and

3. Lastly, the salaries of the Muslim employees are automatically deducted through an automatic check-off system, i.e. the Muslim employee salary is deducted by their employer.

3. These amounts of deduction are dependent on the employees' monthly gross earnings and are channelled through the CPF and Majlis Ugama Islam Singapore (MUIS) as the collecting agent. The collections are used to sponsor charitable purposes such as in the 


\section{ANWAR ALLAH PITCHAY, MOHAMAD ISA ABD JALIL, MEGAWATI SOEKARNO \& MOHAMED ASMY MOHD THAS THAKER}

building and maintaining of mosques, Da'wah centres, and running educational programmes.

Similarly, a public Waqf system which has been practised in Malaysia, Turkey, India, Pakistan and Bangladesh is the Corporate Waqf Scheme (CWS)(Abdel Mohsin, 2013). Despite its term, the founder of the scheme is not restricted to either private or public corporations. For example, the Malaysian Wakaf An-Nur Corporation Berhad (WanCorp) established under Johor Corporation (JCorp.) was the first corporate Waqf. Tan Sri Muhammad Ali Hashim (former CEO of JCorp.) himself practised CWS in the year 2006. JCorp established WanCorp and allocated RM 200 million of JCorp's net assets as Waqf to WanCorp. This corporation was established to manage its Waqf organisations such as Larkin Sentral and TPM Management Sdn Bhd. A periodical report by Bank Muamalat (2012) declared that the current accrued total asset of WanCorp is RM538 million. Hashim (2012) says WanCorp has operated seventeen (17) clinics throughout Malaysia, which have attended to an excess of 800,000 patients with a small fee of RM5 that covers doctor's consultation plus medicine. The following is the detail of this model:

1. The initial founder, either a public or private corporation identified as the mother corporation/principal founder; will launch an associated Waqf institution as the trustee.

2. The principal founder will then request the subsidiaries to contribute their dividends or part of their profit to the corporate Waqf regularly; as well as calling for cash Waqf contributions from donors such as individuals, companies and institutions to this associated Waqf institution. 3. As the trustee, the Associated Waqf institution will administer and invest the collected cash Waqf from the various contributors.

3. The revenue generated is then channelled to specific ventures following deduction from operational expenses.

Based on these prevailing models of cash Waqf, this present study aims to propose an improved version of compulsory cash Waqf scheme (CCWS), which is called the Waqf Percentage Model (WPM) model. The following Figure 1 illustrates the proposed Waqf Percentage Model (WPM):

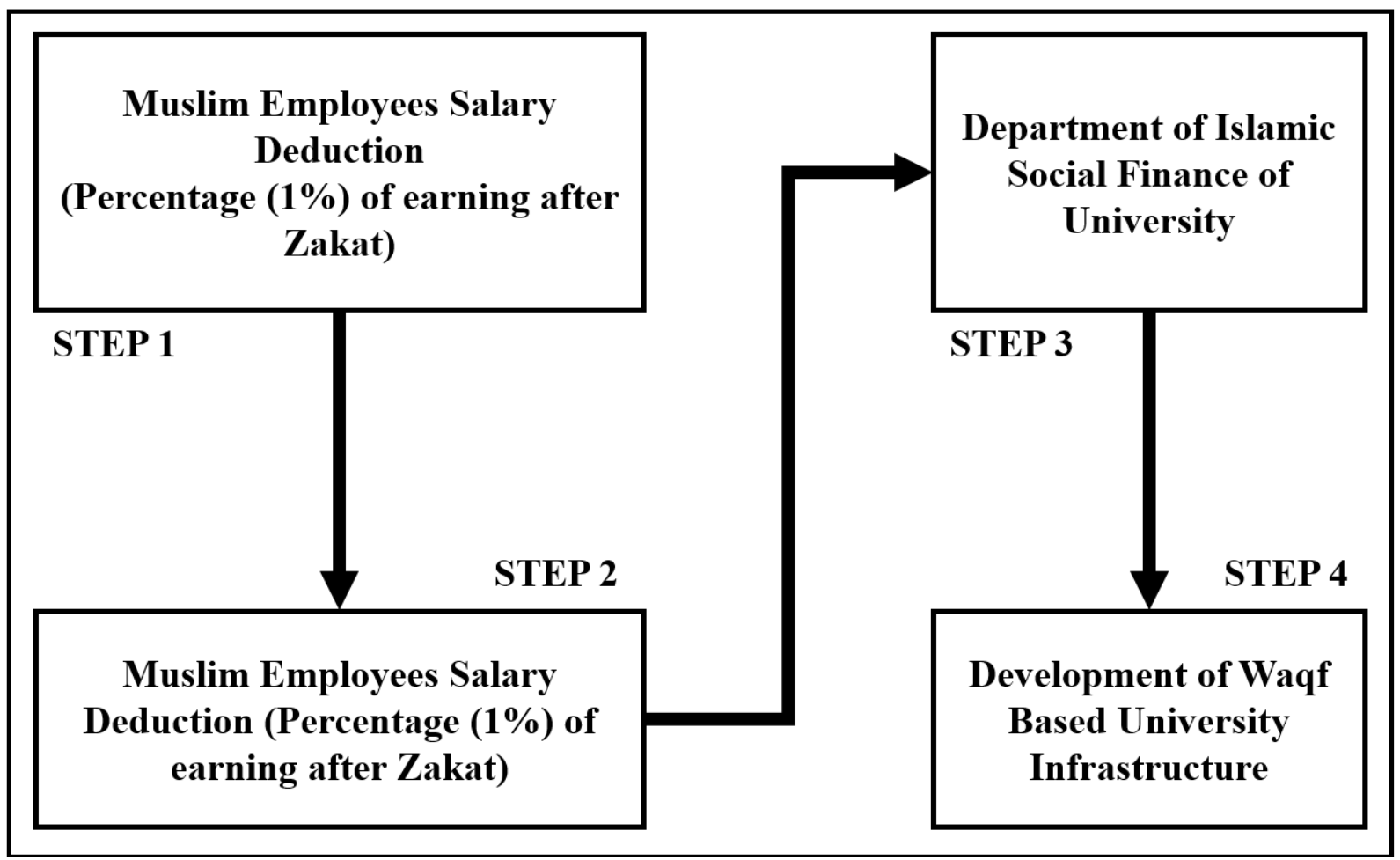

Figure 1. Waqf Percentage Model (WPM) 
Table 1. WPM Model explanation

\begin{tabular}{ll}
\hline STEP 1 & $\begin{array}{l}\text { The cash Waqf is collected through salary deduction of Muslim employees of the } \\
\text { university. The employees will pay cash Waqf based on } 1 \% \text { of earning after Zakat } \\
\text { deduction. }\end{array}$ \\
\hline STEP 2 & The Treasurer of the university will deduct the Muslim employees' cash Waqf. \\
\hline STEP 3 & The Treasurer will channel the cash Waqf to the Department of Islamic Social Finance. \\
\hline STEP 4 & $\begin{array}{l}\text { The Department of Islamic Social Finance will channel the cash Waqf for the } \\
\text { development of the university's Waqf based infrastructure. }\end{array}$ \\
\hline
\end{tabular}

The WPM model is adapted based on Compulsory Cash Waqf Scheme (CCWS), and the proposal is compared to existing models such as Yayasan Pembangunan Ekonomi Islam Malaysia (YaPIEM), Johor Corporation (JCorp), Wakaf Bank Islam, and Dewan Perniagaan Islam Selangor. These models are shown in Table 2: 
Table 2. Model comparison

\begin{tabular}{|c|c|c|c|c|c|}
\hline & $\begin{array}{l}\text { Waqf } \quad \text { Percentage } \\
\text { Model (WPM) }\end{array}$ & $\begin{array}{l}\text { Compulsory } \quad \text { Cash } \\
\text { Waqf Scheme (CCWS) } \\
\text { MUIS }\end{array}$ & $\begin{array}{l}\text { YaPIEM Sadaqatul } \\
\text { Jariah }\end{array}$ & $\begin{array}{l}\text { JCorp Kumpulan Wakaf An- } \\
\text { Nur (KWAN) }\end{array}$ & $\begin{array}{l}\text { Wakaf Bank } \\
\text { Islam }\end{array}$ \\
\hline $\begin{array}{l}\text { The Amount of } \\
\text { Cash Waqf and } \\
\text { Method }\end{array}$ & $\begin{array}{l}\text { The proposed amount of } \\
\text { cash Waqf is based on } \\
1 \% \text { of earning after zakat } \\
\text { (Salary Deduction } \\
\text { method) }\end{array}$ & $\begin{array}{l}\text { The contribution is } \\
\text { found in the form of } \\
\text { currency amount starting } \\
\text { with } \$ 1.00-\$ 7.00 \\
\text { (Salary Deduction } \\
\text { method) } \\
* \$=\text { Singapore Dollar }\end{array}$ & $\begin{array}{l}\text { The contribution is } \\
\text { based in the way of } \\
\text { currency amount with } \\
\text { a minimum amount of } \\
\text { RM5.00 (Salary } \\
\text { Deduction method) }\end{array}$ & $\begin{array}{l}\text { Amount of contribution is based } \\
\text { on the share price. } \\
\text { (Share in Bursa Malaysia) }\end{array}$ & 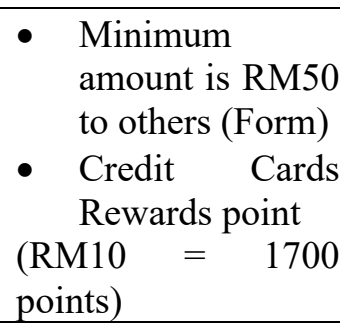 \\
\hline $\begin{array}{l}\text { Objectives/ } \\
\text { Beneficiaries }\end{array}$ & $\begin{array}{l}\text { The collection of Cash } \\
\text { Waqf will be used for the } \\
\text { development of the } \\
\text { university's Waqf based } \\
\text { infrastructure. }\end{array}$ & $\begin{array}{l}\text { Collection of Cash Waqf } \\
\text { is invested in Shariah } \\
\text { Compliance Investment, } \\
\text { and the return on } \\
\text { investment is dispersed } \\
\text { to Education/ Madrasah }\end{array}$ & $\begin{array}{l}\text { Sponsoring "Amal } \\
\text { Jariah" program }\end{array}$ & $\begin{array}{l}\text { The dividend generated from the } \\
\text { Waqf Shares are divided into } \\
\text { three main objectives; first is } \\
70 \% \text { of the return is reinvested } \\
\text { into shares, while } 25 \% \text { of the } \\
\text { return is channelled into } \\
\text { education, social development, } \\
\text { health, entrepreneur and, 5\% is } \\
\text { directed to Johor State Religious } \\
\text { Council (MAIJ) }\end{array}$ & $\begin{array}{lr}\text { Wakaf } & \text { Khas } \\
\text { (sponsored } & \text { specific } \\
\text { Waqf r based } \\
\text { development. E.g. } \\
\text { Sekolah Menengah } \\
\text { Agama Al Madrasah } \\
\text { Al Alawiyah Ad } \\
\text { Diniah Yayasan } \\
\text { Islam Perlis }\end{array}$ \\
\hline
\end{tabular}




\section{Research method}

This study utilised the qualitative approach, which is a series of interviews to accomplish its objectives. These interviews were conducted with academic experts from different fields across varying related positions such as Senior Lecturer, Associate Professor, Professor, Director of Zakat and Waqf, Director of Mosque and Bursary of SZZ university with the purpose to develop a better comprehension of the Waqf Percentage Model (WPM) and appraise its suitability, applicability and prospects in the market. The steps in the qualitative analysis, as suggested by Creswell (2014) include:

i) Preliminary exploration of the data by reading through the transcripts and writing memos,

ii) Coding the data by segmenting and labelling the texts,

iii) Using codes to develop themes by aggregating similar codes together,

iv) Connecting and interrelating themes and

v) Constructing a narrative.

The selection of specialists was based on purposive sampling. Being one of the most common sampling strategies, purposive sampling is where the respondents are pre-selected based on specific research inquiries. Purposive sample sizes are often established on the ground of theoretical saturation (the point in data collection when new data do not add any new understandings to the research questions). This study focuses on expert sampling, where the experts were identified from varying positions, as shown in Table 1. The selection criteria for these experts were determined by their credentials, areas of concentration and career experience.

In terms of the number of respondents, this study follows the recommendation by Morse (1994), who suggested six respondents for any qualitative studies. That number of respondents (six) has also been used by other researchers such as Muhammad (2012) and Ahmed (2013). In their perspectives, researchers who work with small sample sizes could study their subject matter in-depth and is sufficient in accomplishing the objectives of the study. Additionally, the concept of 'saturation' or the point at which no new information or themes are observed in the respondents' data also determines the number of the said respondents. Data collected during the interviews were transcribed into field notes and analysed by using thematic analysis, which according to Braun and Clarke (2006), is "a method for identifying, analysing and reporting patterns (theme) within data".

\section{Respondent and study area}

The study is conducted in one of the oldest public university in Malaysia. The first and second objectives of the study are achieved by interviewing relevant staff that has involved in doing research and managing Islamic Social Finance funds such as Waqf and Zakat in the university. The following Table 3 shows the list of the respondents who participated in the present study.

Table 3. Profile of the interviewees

\begin{tabular}{llll}
\hline No. & Institution & Position & Code \\
\hline 1. & Universiti SZZ & Senior Lecturer & A1 \\
2. & Universiti SZZ & Associate Professor & A2 \\
3. & Universiti SZZ & Professor & A3 \\
4. & Universiti SZZ & Director of Waqf \& Zakat & A4 \\
5. & Universiti SZZ & Director of the Mosque & A5 \\
6. & Universiti SZZ & Bursary & A6 \\
\hline
\end{tabular}




\section{ANWAR ALLAH PITCHAY, MOHAMAD ISA ABD JALIL, MEGAWATI SOEKARNO \& MOHAMED ASMY MOHD THAS THAKER}

The following Table 4 shows the categorical themes and interview questions used in the present study.

Table 4. Categorical themes and interview questions

\begin{tabular}{ll}
\hline No. Categorical Themes & Interview Questions \\
\hline 1. & $\begin{array}{l}\text { The significance of Waqf } \\
\text { practise in the domain of higher essential for the progress of a country like Malaysia? } \\
\text { education }\end{array}$ \\
\hline $\begin{array}{l}\text { What is the current model of } \\
\text { Waqf practised in the the university? } \\
\text { iniversity? (Effective or } \\
\text { ineffective) }\end{array}$ \\
$\begin{array}{l}\text { New proposed model and its } \\
\text { suitability in the perspective of sustainability in the context of higher education? } \\
\text { higher education }\end{array}$ \\
\hline $\begin{array}{l}\text { Sustainability of the new model } \\
\text { 4. In your perspective, what would be the contributing factors in } \\
\text { the sustainability of the new model? }\end{array}$ \\
\hline $\begin{array}{l}\text { Challenges of proposing this } \\
\text { new model into the higher of a new Waqf model into the higher education system? } \\
\text { education system }\end{array}$ \\
\hline
\end{tabular}

The analysis technique used in this study is 'Interpretational Analysis'. This approach would look for patterns (threads, constructs, commonalities, etc.) with the data which explain the phenomenon. Therefore, the collected data were transcribed, and they were then filtered according to the pattern or commonalities among the respondents.

\section{Data analysis and findings}

The results were discussed according to the interviews questions.

\section{What is the importance of waqf practise in the context of higher education?}

The interview respondents were queried for their perspectives on the significance of Waqf practice in the context of higher education for the development of a country like Malaysia. Overall, the economic and social importance of Waqf practises in the context of higher education was strongly agreed upon by the respondents $(n=4)$. Below are some of their verbatim responses:

[...] important in the context of higher education [...] can help our education to go further. (A1)

Waqf gives off a significant impact for education starting from an early education till to the university level [...] significant for the development of education in Malaysia [...] one of the government's alternative to enhance the country financial resources [...] to sustain the higher education. (A4)

Waqf plays a significant role as one of Islamic financial instrument [...] needs to be practised with an objective and make sure it can be accepted generally [...] Waqf is one of the significant potentials in education, it can be sustained by setting up a clear vision and mission. (A5) 
Higher education is currently going for income diversification [...] we need to look for other revenue stream or funding other than what is government giving [...] university is moving towards trying to be innovative in generating income [...] higher education is now trying to tap into this potential funding stream which is not new to the Islamic country, but it is not capitalised by higher education (A6)

According to the respondents, Waqf plays an essential role in higher education. Waqf contributes to the enhancement of financial resources; having a significant impact on education and promoting income diversification.

\section{What is the current model of waqf practised in the university? (effective or ineffective)}

The respondents conveyed their views on the current model of Waqf practised in the university. Every one of them $(n=6)$ mentioned that the current model of Waqf practised in the university is valid with some constraints. The following views were collected:

The current model of Waqf practised in the university is useful, but it is not quite diverse. The cash Waqf is not fully utilised as they do not expose how much they have collected and spent [...] it needs to be transparent [...] cannot see what do they contribute to. (A1)

Effective [...] but we have to know that Waqf is under the control of Majlis Agama Islam (A4)

The current model needs the permission from Majlis Agama Islam [...] university needs to be appointed as the Mutawalli [...] the model needs to have firm planning [...] the trustee needs to convert the current asset to the fixed asset as quickly as possible once the fund has reached its stated amount [...] the effectiveness depends on the committee (A5)

University acknowledged it as a potential stream, but it comes with some constraints in term of governance [...] for instance controlled by Majlis Agama Islam [...] Majlis Agama Islam needs to allow the fund-collecting by giving the certification [...] the current model is encouraging university to improve Waqf model [...] with the tax exemption of $10 \%$ announced by the government recently in future Waqf model can move forward. (A6)

The above findings reveal that all the respondents agree that the current model of Waqf practised in the university has some constraints. The respondents cited the following factors leading to these constraints: the control from Majlis Agama Islam, lack of diversity and incomplete utilisation.

\section{How suitable is the new proposed model in the context of higher education?}

Next, the respondents were asked for their thoughts on the significance of the Waqf Percentage Model. They $(\mathrm{n}=4)$ conceded that the said model has potential and would go further if there is an improvement in it. The following verbatim responses were collected:

The proposed model is okay [...] make it to voluntary basis instead of compulsory because we do not know other people probably has other commitment even if it is just 1\% deduction [...] can Waqf be preferable to be used for Muslim purposes first before considering to other religion. (A1)

The model is fine, but it could be a burden for the employees because there is a lot of deduction being carried on with the same goals [...] need to set a precise aim or benefits 


\section{ANWAR ALLAH PITCHAY, MOHAMAD ISA ABD JALIL, MEGAWATI SOEKARNO \& MOHAMED ASMY MOHD THAS THAKER}

in collecting the fund [...] the 1\% challenge probably cannot be carried on all of the employees. (A4)

The model can be seen as an excellent effort to introduce the Waqf model in future [...] there's awareness on Waqf to be further developed for university [...] need to start with spreading the awareness, knowledge and understanding to see the impact [...] it involves trust and needs to be work on with integrity. (A5)

The model is a good move however for staff to agree on the 1\% deduction; we cannot make it as compulsory [...] while it is practical to implement it needs a lot of promotion [...] make sure it is based voluntarily [...] it is a challenging topic. (A6)

Based on the above findings, the respondents declared that the proposed model in this study is good. However, it must be made as a voluntary basis and not as compulsory to all the employees.

\section{How sustainable is the new model?}

In the context of the applicability of the Waqf Percentage Model, the respondents were further requested to share their opinions on its sustainability. The majority of the respondents $(n=4)$ mentioned that sustainability could be seen through a few different aspects. The following verbatims were collected based on the interviews:

The sustainability of the new model can be seen through the development of Waqf based university infrastructure [...] we hardly can see the infrastructure in the university being built by the Waqf fund [...] to be used by the especially B40 students. (A1)

One of the main factors that contribute to the sustainability of the new model has to be law [...] to protect the Waqf has been developed [...] Waqf can be seen as sustainable ever since years ago. (A4)

To decide on the sustainability, we need to see how successful the current assets will be converted to the fixed assets [...] Waqf needs to have the element that is fixed because its benefits can last to hundred years. (A5)

The model must be able to get the buy-in while it is direct [...] it must have a good cause [...] the employees need to know where will the fund go to. (A6)

These outcomes established that the respondents highlighted that this model needs to have a good cause. If the sustainability of the model needs to be maintained, it is necessary to ensure the model has a good reason and be successfully converted to the fixed asset. Conversely, the features of the model are also crucial in warranting its sustainability. The participation in it must come from someone who has the capacity and capability to sustain the processes and generation of revenue.

\section{What are the challenges of proposing the new model into the higher education system?}

The next inquiry concentrated on the respondents' observation of impending challenges that will arise in the implementation of the Waqf Percentage Model. They $(n=4)$ generally anticipated that the Waqf Percentage Model would encounter difficulties in the public consciousness. The following are extracts of the respondents' assessments:

The first challenge is to propose the salary deduction [...] does the Waqf model can solve the social problem? [...] to address poverty, education, financial inclusions [...] will it 


\section{helps enhance the ranking of the university. (A1)}

The level of understanding of the proposed model [...] Waqf is not about the effort of getting the fund, but it is a platform for us to do a voluntary charity. (A4)

The first challenge would be the level of awareness, knowledge and confidence in carrying the proposed model [...] the trustee must be someone who knows to change the current asset to the fixed asset [...] the committee needs to work with the system that can ease people to contribute to Waqf [...] need to give a distinct purpose on the proposed Waqf model and use methods with integrity [...] must start with the higher-ups first. (A5)

One of the challenges is to get the buy-in [...] not everyone would agree on deducting the $1 \%$ from their salary [...] some wants to know what is the purpose of that $1 \%[\ldots]$ at the end of the day to make people understand about the organisation. (A6)

These observations show that the main challenge is awareness. Awareness is fundamental to ensure the success of the model. Today we see a significant lack of knowledge of the Waqf practice within the society. The other obstacle pertains to the goals, where the model needs to have a firm preparation and a clear purpose.

\section{Conclusion}

This study offers an in-depth analysis of dialogues conducted with respondents from various fields. The discoveries from the interviews have supported the appropriateness of the Waqf Percentage Model in providing significant financial amenities. The results also underlined the significance of managing the Waqf Percentage Model as a separate entity to both the SIRC and the corporate sector. Furthermore, the interviewees have highlighted that the main drivers of the model's sustainability are the characteristics of the model, including the awareness of impending challenges within its implementation.

From the respondents' viewpoint, there is considered an agreement of the model's viability in providing financial amenities. It delivers an alternative approach to traditional monetary establishments in thus helping the government to decrease expenditures on Waqf improvement. Therefore, they should be a reasonable consideration of its utilisation for our own or even propose it for adoption to other Muslim countries.

The Waqf Percentage model is expected to encourage the circulation of money among the overall society instead of profiting only the already affluent. The benefit of this circulation of public wealth can cease capitalism induced problems in society. Furthermore, this model is expected to enhance the motivation of donors to consistently contribute to the surplus of their wealth for related religious activities. The participation of Muslim employees and corporate companies will improve the economic growth of a nation in a sustainable way instead of the dependence through internal/external borrowings. This allows the promotion of the circulation of wealth within society.

The Waqf Percentage model is expected to enhance national development sustainably and harmoniously. This model reduces the dependency on loan-based development, allowing the coming generation to lead the country sustainably compared to the immediate environment, which is highly volatile with interest rates and inflations.

The limitation of this study is the lack of test in real practice. The proposed model should be tested and applied for at least a couple of months to see the model fitness. Plus, further research is required by Waqf 


\section{ANWAR ALLAH PITCHAY, MOHAMAD ISA ABD JALIL, MEGAWATI SOEKARNO \& MOHAMED ASMY MOHD THAS THAKER}

practitioners and researchers, to identify more gaps in the present system and develop a better hybrid Cash Waqf model not only for Malaysia but also for all over the world.

\section{References}

Abas, F. N., \& Raji, F. (2018). Factors Contributing to Inefficient Management and Maintenance of Waqf Properties: A Literature Review. International Journal of Islamic and Civilisational Studies, 03, 5367.

Cizakca, M. (2000). A History of Philanthropic Foundations: The Islamic World from the Seventh Centuryto the Present (1st ed.). Istanbul, Turkey: Bogazici University Press.

Creswell, J. W. (2014). Research Design: Qualitative, Quantitative and Mixed Methods Approaches (4th ed.). California: SAGE Publications, Inc. https://doi.org/10.1017/CBO9781107415324.004

Gadot, N. (2006). Amalan SahamWakaf Johor. In the Waqf Convention. Malaysia.

Hasan, R., Hassan, M. K., \& Rashid, M. (2019). The Role of Waqf in Educational Development Evidence from Malaysia. Journal of Islamic Finance, 8(1), 1-7.

Hashim, K. F. (2012). PhD Thesis; Understanding the determinants of continuous knowledge sharing intention within business online communities. Auckland University of Technology. Auckland University of Technology. https://doi.org/10.1108/EBR-10-2013-0128

Hassan, M. K., Hasan, R., \& Rashid, M. (2017). Mediating Role of Trust in Cash Waqf Donations. In Revival of Waqf for Socio-Economic Development. Dhaka, Bangladesh: Islamic Research and Training Institute (IRTI).

Ihsan, H., \& Mohamed Ibrahim, S. H. (2011). WAQF Accounting and Management in Indonesian WAQF Institutions. Humanomics, 27(4), 252-269. https://doi.org/10.1108/08288661111181305

Ismail Abdel Mohsin, M. (2013). Financing Through Cash-Waqf: a Revitalisation to Finance Different Needs. International Journal of Islamic and Middle Eastern Finance and Management, 6(4), 304321. https://doi.org/10.1108/IMEFM-08-2013-0094

Mohd Salleh, D. S., \& Muhammad, S. (2008). Waqaf Development in Malaysia: Issues and Challenges. Jurnal Pengurusan JAWHAR, 2 (1), 13-35.

Wu, M. A. (1975). An Introduction to the Malaysian Legal System. Kuala Lumpur: Heinemann Educational Books (Asia). 